Scientific Journal Warsaw University of Life Sciences - SGGW

Problems of World Agriculture volume 17 (XXXII), number 4, 2017: 95-104

DOI: $10.22630 /$ PRS.2017.17.4.85

Nataliya Horin
Ivan Franko National University of Lviv, Ukraine

\title{
Eco-innovative Activity of Ukrainian SMEs
}

\begin{abstract}
The study attempts to investigate the eco-innovative activity of Ukrainian enterprises according to their size (small, medium, and large) with special focus on SMEs as the predominant group of enterprises, which ensure the innovative development of the whole national economy, and is central to the efforts to achieve environmental sustainability and green growth. The empirical analysis is based on a questionnaire survey of 254 Ukrainian enterprises of different sizes; the survey presents data on their current state and foreign trade activity, opportunities and barriers for the implementation of technological innovations and eco-innovations. The relationships between the export and ecoinnovative activities is also explored. The analysis showed that SMEs are less eco-innovative in comparison with large enterprises, have fewer numbers of exporters than large firms, but exporters are more eco-innovative than non-exporters. Also, the size of the Eco-innovation Index for Ukraine was calculated. Based on the obtained results, Ukraine is an economy with a low level of ecoinnovativeness, so, the study is extremely important.
\end{abstract}

Key words: eco-innovation, innovative development, small, medium and large enterprises, exporters, foreign trade activity, Ukraine

JEL Classification: O13, O3, Q5, F18

\section{Introduction}

Innovative development has become the main factor providing international competitiveness of national economies on world markets. Eco-innovation aims to create both economic and environmental values, it plays an increasingly important role in building competitive advantadge of individual enterprises, sectors and whole economies, but in spite of this, ecological innovation is currently a neglected area. According to Kemp (Kemp, 2011), eco-innovation is a prime candidate for "new mission" policies to deal with (interrelated) societal challenges of climate change, resource efficiency, and energy/resource scarcity. Thus, the main purpose of this paper is to analyse the ecoinnovative activity of enterprises according to their size (small, medium, and large), and to determine the relationship of their export activity and eco-innovation. For the investigation we choose Ukraine as an economy with a low level of eco-innovativeness. The economic transformation since 1991 has brought significant changes in the innovative activity of Ukrainian enterprises. Nowadays, they implement new technologies much more actively, but environmental innovations still are not widely adopted.

The understanding of eco-innovation activity of enterprises has been an ongoing topic in practitioner and academic discussion since the 1980s. Different studies emphasized that those entrepreneurs who give importance to collaboration with research institutes, agencies and universities, and to the increase of market demand for green products are more active in all types of eco-innovations (Triguero et al., 2013). Eco-innovations are expected to help

\footnotetext{
${ }^{1}$ Assoc. Prof., Ph.D., Department of International Economic Relations, Sichovykh Strilciv Str. 19, Lviv, 79000, Ukraine, e-mail: talya gorin@yahoo.com, https://orcid.org/0000-0002-0036-6120
} 
finding sustainable solutions for the "grand challenges" such as global warming, tightening supplies of energy, water and food, or public health (Aschhoff et al., 2013).

As it is noted by Rennings and Jaffe et al. (Rennings, 2000; Jaffe et al., 2005), the environmental innovation policy has the dual effect of increasing the innovation across all economic sectors and improving the state of the environment for the benefit of the citizens of the country as well as for the rest of the world.

Cuerva et al. found that technological capabilities such as R\&D and human capital foster the conventional innovations but not the eco-innovations. Moreover, they recommend reducing the financial constraints for SMEs in order to incentivize ecoinnovation (Cuerva et al., 2014).

According to recent studies (Enhancing..., 2017) SMEs play a key role in national economies around the world, generating employment and value-added and contributing to innovation. SMEs are central to the efforts to achieve environmental sustainability and green growth. However, these contributions vary widely across firms and across countries and sectors.

\section{Objectives}

The primary objective of the study is the investigation of the adoption of ecoinnovations by Ukrainian enterprises with a focus on companies of small and medium sizes, mainly those which are involved in export activity, because of a huge lack of the investigations of both innovative and foreign trade activities of SMEs in Ukraine. Moreover, SMEs are regarded as less favored in the innovation diffusion. Most models regarding innovation are focused on the diffusion of new developments within business networks and clusters, such as percolation models. If large enterprises, especially multinationals, benefit from a large support network at an international level, SMEs are often isolated, thus reducing their capacity to have access to the newest research (VoicuDorobantu et al., 2011). In Ukraine the systemic monitoring of foreign economic activity of small and medium-sized enterprises generally is not conducted (Pokryshka, 2016). From time to time periodic surveys of this area are carried out either by the domestic research institutes, such as the Institute for Economic Research and Policy Consulting (Ryzhenkov, 2015; Pokryshka, 2016), or by international institutions, such as the World Bank Group (Ukraine..., 2013), and their innovation activities are monitored and analyzed by the State Statistics Service of Ukraine (Scientific..., 2016). However, the implementation of ecoinnovative technologies by the exporters according to their size is not out of sight neither for independent scientists, nor for the whole institutes. That is why the presented analysis of eco-innovative activities of SMEs is one of the most important tasks for theoretical researchers, businessmen and policy-makers.

Other objectives of this paper are:

- to explore the purpose and barriers to implementation of eco-innovation of SMEs;

- to determine the problems and possibilities of the eco-innovative development of SMEs in Ukraine. 


\section{Data sources and research methods}

In the study three comparative and descriptive methods were applied in the analysis of the research problem. Data used for the comparative analysis are taken from the databases of the State Statistics Service of Ukraine, the Eurostat and OECD official statistics. The information framework of the paper is based on Ukrainian and the EU member laws and regulations in eco-innovation policies, and scientific publications.

Empirical analysis of the literature revealed the most important problems to ecoinnovation of SMEs, especially in the case of Ukraine.

Based on the Eco-Innovation Scoreboard as the first tool to assess and illustrate ecoinnovation performance across the EU Members, we have calculated the size of the Ecoinnovation Index for Ukraine. This index aims at capturing the different aspects of ecoinnovation by applying 16 indicators grouped into five thematic areas: eco-innovation inputs, eco-innovation activities, eco-innovation outputs, resource efficiency and socioeconomic outcomes. It has allowed us to show how well Ukraine performs in different dimensions of eco-innovation compared to the EU Members.

This paper is based on a structured interview as a method of data collection in quantitative research to reveal the main directions and drivers to eco-innovation of Ukrainian enterprises, and to determine the concept of innovative development through implementation of eco-innovations by SMEs.

\section{Research results}

The analyses of Ukrainian eco-innovative development based on the Eco-Innovation Scoreboard Index indicators has shown that Ukraine is a country with a low level of ecoinnovative efficiency (Figure 1). Ukraine was in the penultimate position in comparison with other EU Members with the result of 34 points in 2015 (Environmental..., 2016). Bulgaria and Poland are rated a bit better with the results of 49 and 59 points.

Analyzing the results of the eco-innovation index in terms of individual groups of indicators, it can be noted that the relatively strongest area of Ukrainian eco-innovation is the area of the achieved results (it is placed before Bulgaria). In the other four areas expenditures on eco-innovation, eco-innovation activity, social and economic effects resulting from the introduction of eco-innovation, and achieved environmental effects Ukraine takes the last position.

Following the results of the Eco-Innovation Index it should be emphasized that Ukraine needs more effective state-supported programs of eco-innovation and sustainable development. The Ukrainian government also regards eco-innovation as part of the growth strategy of the national economy, but researchers noticed that in practice, however, these goals are not treated as priorities, and the institutions supporting the innovation consider environmental issues to be of secondary importance. But nowadays, Ukraine has a wide range of possibilities for both conducting research and introducing eco-innovation projects by enterprises of different sizes. 


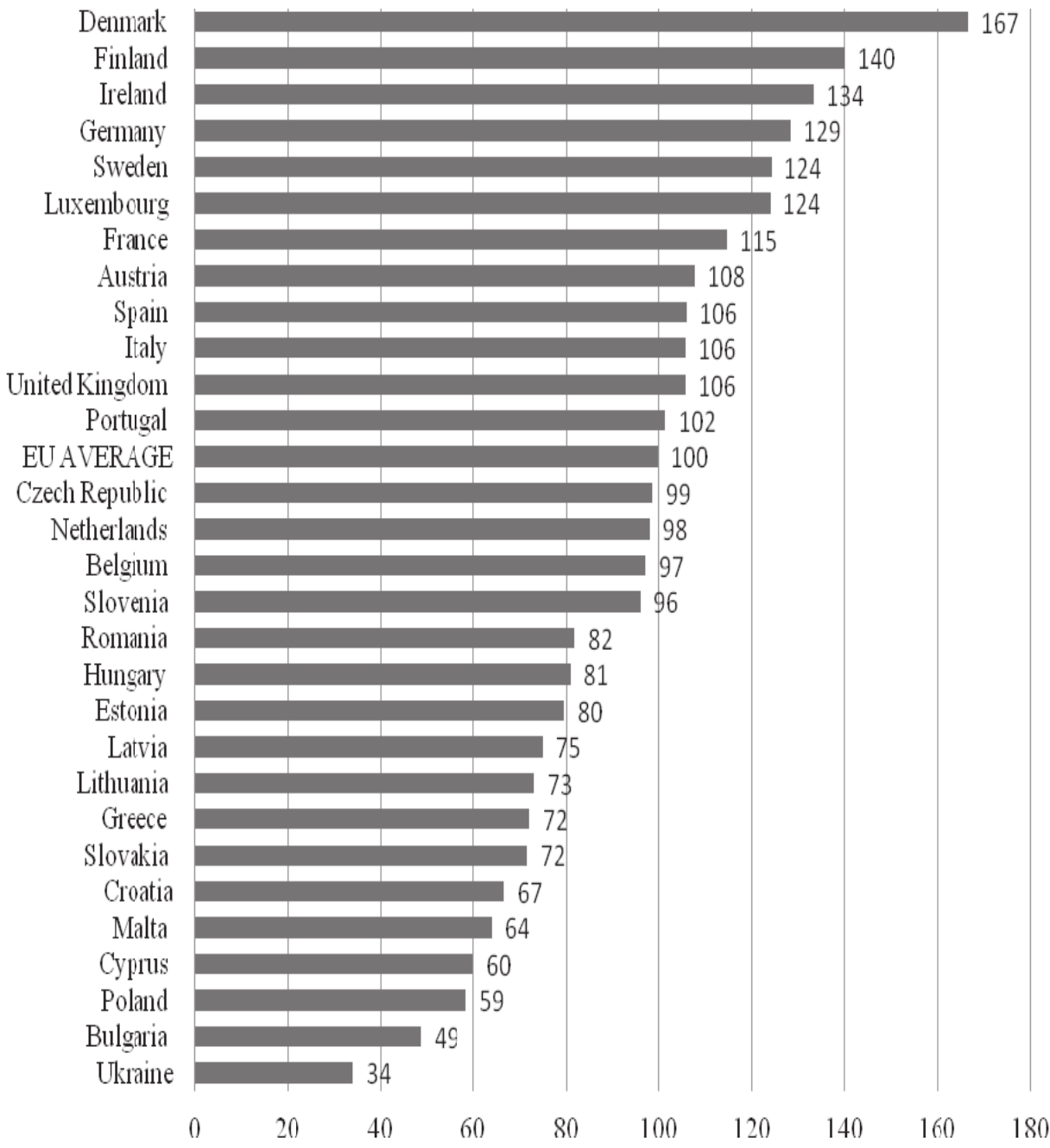

Fig. 1. Eco-innovation Index for EU-28 and Ukraine, 2015

Source: own compilation based on (Hrabynskyi et al., 2017 A) (in case of Ukraine) and on (The EcoInnovation..., 2016) (in case of the EU).

It should be emphasized that in Ukraine SMEs are the predominant form of enterprises, accounting for approximately $99.7 \%$ of all firms. The indicators that show the weight of SMEs in national economy confirm their importance for economic growth. According to the State Statistics Service, in Ukraine SMEs provide about $72.6 \%$ of jobs and contribute $52.5 \%$ of value added (The official...). In addition, eco-innovative development of SMEs can contribute to economic diversification and resilience. This is especially relevant for resource-rich countries that are particularly vulnerable to commodity price fluctuations. 
It should be noted that a standard international definition of small and medium-sized enterprise does not exist. SMEs are defined differently in the legislation across countries, in particular because the dimension "small" and "medium" of a firm are relative to the size of the domestic economy. The most common factor determining the size of enterprises is the number of people employed. According to this factor the World Bank divides enterprises into three groups: small $-1-19$, medium - 20-99, and large - more than 100 employees (Ukraine..., 2013). The OECD refers to SMEs as the firms employing up to 249 persons, with the following breakdown: micro (1 to 9), small (10 to 49) and medium (50-249). Large enterprises have more than 250 employees. This provides for the best comparability given the varying data collection practices across countries, noting that some countries use different conventions (Enhancing..., 2017).

In the study, the classification of enterprises is based on the Ukrainian laws, which determined that small-sized enterprises employ less than 50 people, medium-sized - from 50 to 249 people, large-sized - 250 or more people (Economic...). The same classification method is used by the Ukrainian Institute for Economic Research and Policy Consulting (Ryzhenkov, 2015).

During the period from $10^{\text {th }}$ of September 2016 through $22^{\text {nd }}$ of December 2016 we collected data received from the telephone interviews with business owners and topmanagers in 254 Ukrainian enterprises. For more probability of the analysis, the survey covered about the same number of different-sized enterprises - 88 large, 84 medium and 82 small enterprises. The survey was concerned the participation of enterprises in foreign trade activity, and the present situation, opportunities and barriers in the implementation of technological and environmental innovations. Geographical coverage of the study: all regions of Ukraine, except for the temporarily occupied territory of the Autonomous Republic of Crimea, Sevastopol and parts of the zone of anti-terrorist operation.

Table 1 shows the results of the survey of Ukrainian small, medium and large-sized enterprises regarding their innovation activity. Additionally, the implementation of ecoinnovations was also evaluated.

Table 1: Innovation activity of Ukrainian enterprises according to their size

\begin{tabular}{|c|c|c|c|c|c|c|c|}
\hline & \multirow[b]{2}{*}{$\begin{array}{c}\text { Total } \\
\text { number of } \\
\text { surveyed } \\
\text { enterprises }\end{array}$} & \multicolumn{4}{|c|}{ Innovation-active enterprises } & \multicolumn{2}{|c|}{$\begin{array}{c}\text { Non-innovative } \\
\text { enterprises }\end{array}$} \\
\hline & & Number & $\begin{array}{l}\% \text { of total } \\
\text { number of } \\
\text { surveyed } \\
\text { enterprises }\end{array}$ & $\begin{array}{l}\text { Number of } \\
\text { firms with eco- } \\
\text { innovation } \\
\text { activities, \% of } \\
\text { total number of } \\
\text { innovation- } \\
\text { active firms }\end{array}$ & $\begin{array}{c}\% \text { of total } \\
\text { number of } \\
\text { innovation- } \\
\text { active } \\
\text { enterprises }\end{array}$ & Number & $\begin{array}{c}\% \text { total } \\
\text { number of } \\
\text { surveyed } \\
\text { enterprises }\end{array}$ \\
\hline $\begin{array}{l}\text { Total } \\
\text { including }\end{array}$ & 254 & 57 & 22,4 & 19 & 33,3 & 197 & 77,6 \\
\hline Small & 82 & 8 & 9,8 & 2 & 24,9 & 74 & 90,2 \\
\hline Medium & 84 & 18 & 21,4 & 5 & 27,8 & 66 & 78,6 \\
\hline Large & 88 & 31 & 35,2 & 12 & 38,7 & 57 & 64,8 \\
\hline
\end{tabular}

Source: Author's own elaboration. 
In Ukraine the eco-innovative activities of firms of all sizes are growing but SMEs are less eco-innovative in comparison with large enterprises. The low eco-innovation of SMEs is due to poor results in research and development as well as investments in environmental technologies. In 2015 their eco-innovative activity was funded almost entirely from their own sources ( $85 \%), 0,7 \%$ - from state and local budgets, $0.8 \%$ - by loans, and $1.3 \%$ - by domestic and foreign investment [Scientific... 2016].

In the study the companies were divided into the groups with respect to their participation in export activities (Table 2).

Table 2. Groups of enterprises by size with respect to their participation in export activities

\begin{tabular}{|c|c|c|c|c|c|c|c|c|c|c|c|c|}
\hline & 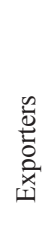 & La & 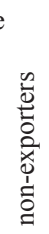 & $\%$ & 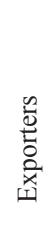 & $\mathrm{Mc}$ & 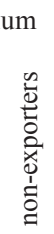 & $\%$ & 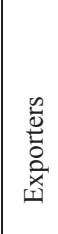 & $\%$ & 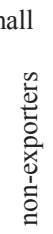 & $\%$ \\
\hline $\begin{array}{l}\text { Total } \\
\text { Including: }\end{array}$ & 66 & 100 & 22 & 100 & 20 & 100 & 64 & 100 & 12 & 100 & 70 & 100 \\
\hline Innovative & 16 & 24,2 & 3 & 13,6 & 5 & 25,0 & 8 & 12,5 & 2 & 16,7 & 4 & 5,7 \\
\hline Eco-innovative & 8 & 12,1 & 4 & 18,2 & 3 & 15,0 & 2 & 3,1 & 1 & 8,3 & 1 & 1,4 \\
\hline $\begin{array}{l}\text { Neither innovative, } \\
\text { nor eco-innovative }\end{array}$ & 42 & 63,6 & 15 & 68,2 & 12 & 60,0 & 54 & 84,4 & 9 & 75,0 & 65 & 92,9 \\
\hline
\end{tabular}

Source: Author's own elaboration.

As Table 2 shows, large enterprises are the most innovative and active, and implement eco-innovations more often than SMEs. Also, SMEs have fewer exporters than large firms. This is largely due to the fact that, firstly, the large companies have better access to the internal capital, some of which they can allocate to innovations, including to ecoinnovations, the more so, because their business is often environmentally polluting. Secondly, the large companies are better able to obtain loans. Thirdly, they have greater volume of products which they might bring to the external markets and remain competitive on the international level. According Galliano and Nadel (Galliano \& Nadel, 2013), the structuring role of firms' internal characteristics, co-evolution with other forms of innovation, and the influence of firms' external environments on their eco-innovation adoption are the most important determinants of firms' eco-innovation and export behavior. As our previous analysis shows, in the case of SMEs the export activities positively influence the implementation of eco-innovations (Hrabynskyi et al., 2017 B).

In general, the eco-innovation projects of SMEs focuses on the reduction of materials or water consumption per unit of output, and the reduction of energy consumption or carbon footprint (Table 3). High costs of energy, water or materials cause the enterprises to look for the ways and instruments of the optimization and decreasing their use. 
Table 3. Types of eco-innovations implemented in Ukrainian enterprises according to their size, $\%$ of total number of enterprises with eco-innovation

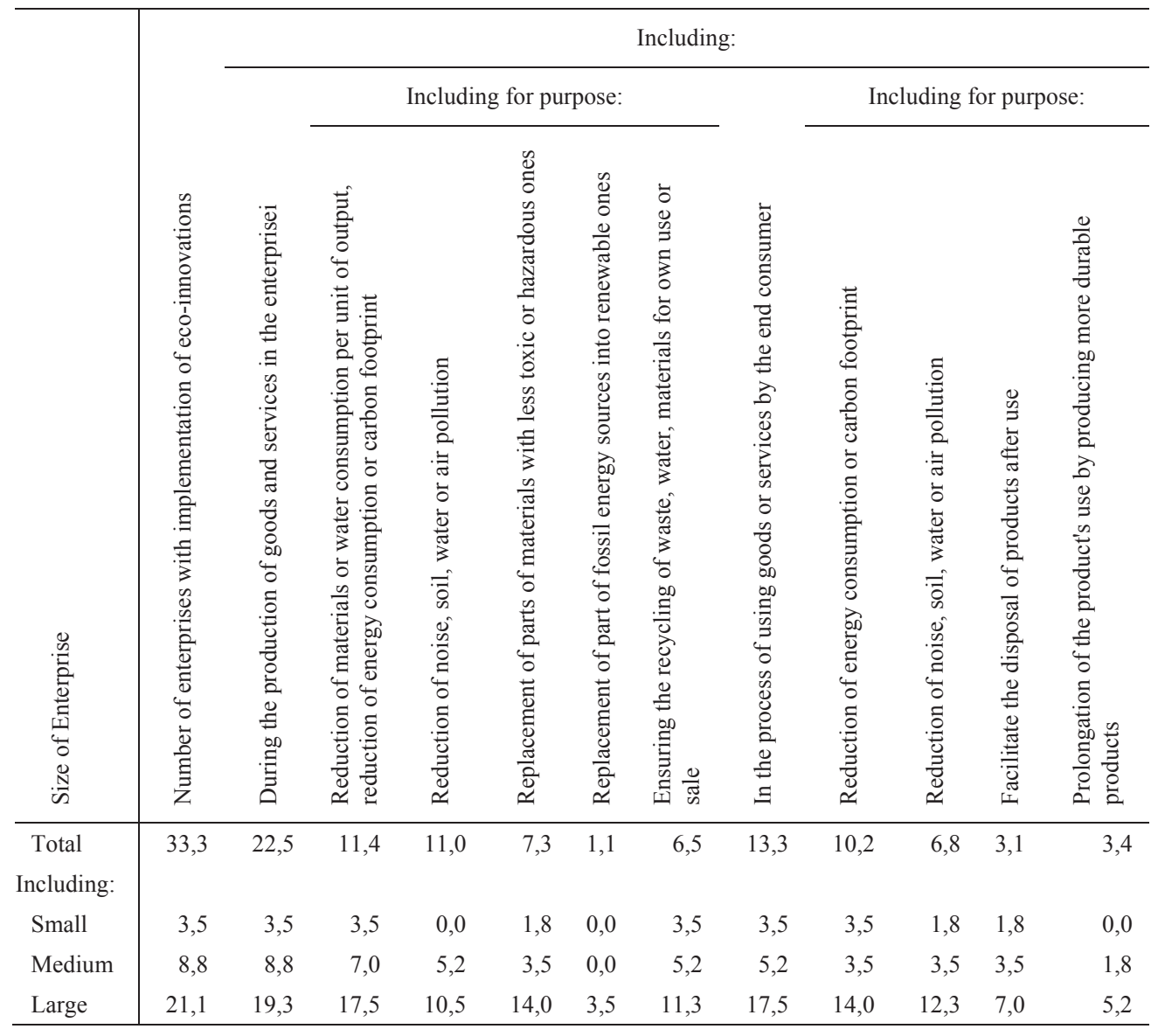

Source: Author's own elaboration

In general, five groups of drivers of eco-innovation are defined in literature (Rennings et al., 2003): regulation, demand from users, capturing new markets, cost reduction and firm's reputation. We use this classification to estimate the importance of each of these group for Ukrainian business' eco-innovation activity. So, the most important drivers of ecoinnovative activity of SMEs in Ukraine are as follows (Table 4): existing and expected environmental regulations and taxes, and the reduction in operating costs on energy, water and materials. 
Table 4. Drivers of firms' eco-innovation activity in Ukraine, \% of total number of enterprises with eco-innovation*

\begin{tabular}{|c|c|c|c|c|c|c|c|c|c|}
\hline & 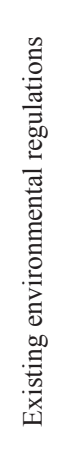 & 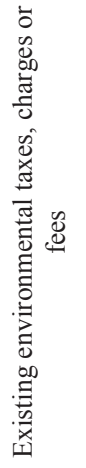 & 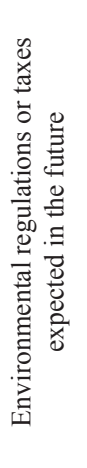 & 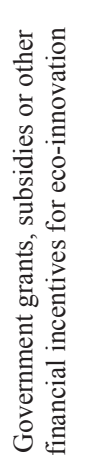 & 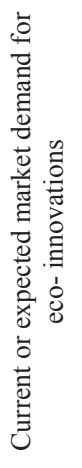 & 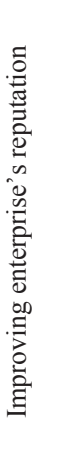 & 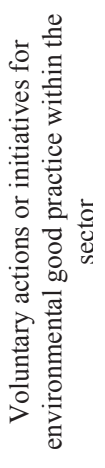 & 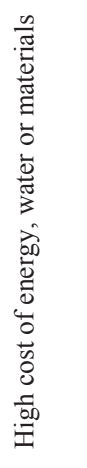 & 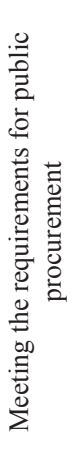 \\
\hline $\begin{array}{l}\text { Total } \\
\text { Including: }\end{array}$ & 12,4 & 9,5 & 5,5 & 1,7 & 2,4 & 3,4 & 4,5 & 9,7 & 7,8 \\
\hline Small & 3,5 & 3,5 & 1,8 & 0,0 & 0,0 & 0,0 & 0,0 & 3,5 & 1,8 \\
\hline Medium & 8,8 & 8,8 & 3,5 & 0,0 & 1,7 & 1,7 & 1,7 & 8,8 & 1,7 \\
\hline Large & 21,1 & 19,3 & 8,7 & 1,7 & 1,7 & 10,5 & 7,0 & 21,1 & 10,5 \\
\hline
\end{tabular}

Source: Author's own elaboration.

In the case of SMEs, it should be noted that this group of firms are often characterized by the more flexible structures and ability to adapt to changes. They are not burdened with numerous managerial levels, large fixed assets, or strategic commitments to their employees, customers, suppliers. It is much easier for a small or medium firm to track their employees' activities and reward their efforts or successful innovations. Since resources for micro-enterprises are less available, small firms are motivated to choose their innovative projects more carefully, giving preference to those with the greater likelihood of success.

\section{Conclusions}

Nowadays eco-innovations are vital for the development of each country all over the world. They raise the competitiveness of the national economy on the international markets, provide export growth, lead to sustainable economic development, and foster the transition to a green economy. The analyses of Ukrainian eco-innovative development based on the Eco-Innovation Index indicators shown that in comparison with other EU Members Ukraine is the country with the lowest level of eco-innovativeness. Its expenditures on ecoinnovation, eco-innovation activity, social and economic effects from the introduction of eco-innovation, and achieved environmental effects are on the insufficient scope. This negative situation is deepened with low state support of eco-innovation, low level of funding for implementation of eco-innovation projects, the lack of the long-term credits for eco-innovative activity of enterprises. In order to increase the effectiveness of state ecoinnovation policy it is necessary to introduce the conception of formation of a priority instruments system of national eco-innovation policy that has to ensure the effective 
environmental protection with the minimum of cost, and to reorient from the direct budget financing of eco-innovation projects to the indirect policy instruments.

As the systematic monitoring of eco-innovative and foreign trade activities of SMEs are not carried out in Ukraine, the study was focused on this group of enterprises. Evaluation of SMEs' eco-innovation activity showed that, in general, they are often isolated from the eco-innovative development, and regarded as less favored in the innovation diffusion despite of their important role in economic growth and their contribution to value added.

The empirical analysis confirmed the relationships between the export activity and implementation of eco-innovations in SMEs, and showed that SMEs are less eco-innovative in comparison with large enterprises, have fewer exporters than large firms, but exporters are more eco-innovative than non-exporters. The most important drivers of eco-innovative activity of SMEs in Ukraine were indicated as the follows: existing and expected environmental regulations and taxes, and the reduction in operating costs on energy, water and materials. The increasing of market demand for green products caused to higher activity in all types of eco-innovations, but the rising costs of energy, water or materials force the enterprises to look for ways and instruments to optimize and reduce their materials or water consumption per unit of output, and to reduce their energy consumption or carbon footprint.

SMEs in Ukraine have the potential to adopt eco-innovation throughout the structure of their economic activities, to develop new environmental technologies and knowledge as well as to create partnerships and mutual cooperation with research institutions.

\section{References}

Aschhoff, B., Baier, E., Crass, D., Hud, M., Hunermund, P., Kuhler, Ch., Peters, B., Rammer, Ch., Schricke, E., Schubert, T., Schwiebacher, F. (2013). Innovation in Germany - Results of the German CIS 2006 to 2010. Report to the Federal Ministry of Education and Research (BMBF), Mannheim and Karlsruhe, $313 \mathrm{p}$.

Cuerva, M.C., Triguero-Cano, A., Corcoles, D. (2014). Drivers of green and non-green innovation: empirical evidence in Low-Tech SMEs. Journal of Cleaner Production, 68, 104-113.

Economic Code of Ukraine. Accessed from: http://zakon5.rada.gov.ua/laws/show/436-15/print1443702953510543 (In Ukrainian).

Enhancing the Contributions of SMEs in a Global and Digitalised Economy (2017). OECD, Meeting of the OECD Council at Ministerial Level, Paris, 7-8 June, 24. Accessed from: https://www.oecd.org/mcm/documents/CMIN-2017-8-EN.pdf.

Environmental Performance Index. (2016). Accessed from: http://epi.yale.edu/data.

Galliano, D., Nadel, S. (2013). Les déterminants de l'adoption de l'éco-innovation selon le profil stratégique de la firme: le cas des firmes industrielles françaises, Revue d'économie industrielle, 142,(2), 77-110.

Hrabynskyi, I., Horin, N., Ukrayinets, L. (2017 A). Barriers and Drivers to Eco-innovation: Comparative Analysis of Germany, Poland and Ukraine. Economic and Managerial Spectrum, 11(1), 13-24.

Hrabynskyi, I., Horin, N., Ukrayinets, L. (2017 B). Logit and Probit Analysis of Export Behaviour and EcoInnovation Activity of Enterprises under Globalization: Evidence From Ukraine, Globalization and its Socio-Economic Consequences, Proceedings of the 15th International Scientific Conference, Zilina, vol. 1.

Jaffe, A.B., Newell, R.G., Stavins, R.N. (2005). A tale of two market failures: Technology and environment policy. Ecological Economics, 54, 164-174.

Kemp, R. (2011). Ten themes for eco-innovation policies in Europe. Survays and Perspectives Integrating Environment and Society, 4(2). Accessed from: https://sapiens.revues.org/1169.

Pokryshka, S. (2016). Development of export potential of small and medium enterprises as a factor of compensation of loss of traditional foreign markets. Strategic Priorities. Series Economics, 57. Accessed from: http://www.niss.gov.ua/content/articles/files/eksportniy_potensial-69e44.pdf (In Ukrainian) 


\section{N. Horin}

Rennings, K. (2000). Redefining innovation - Eco-innovation research and the contribution from ecological economics. Ecological Economics, 32, 319-322.

Rennings, K., Ziegler, A., Zwick, T. (2003). Employment Changes in Environmentally Innovative Firms. Discussion Paper N01-46. Centre for European Economic Research. Accessed from: $\mathrm{ftp} / / / \mathrm{ftp}$. zew.de/pub/zew-docs/dp/dp0146.pdf.

Ryzhenkov, M. (2015). What prevents exports of Ukrainian enterprises: the point of view of business. Accessed from: www.ier.com.ua/files//Public_events/Expoert_ryzhenkov.pptx (In Ukrainian).

Scientific and Innovative Activity of Ukraine (2016). Statistical Collection. State Statistics Service of Ukraine, Kyiv, 257 p. (In Ukrainian).

The Eco-Innovation Scoreboard and the Eco-innovation Index. (2016). Accessed from: http://ec.europa.eu/ environment/ecoap/scoreboard en.

The official site of the State Statistics Service of Ukraine. Accessed from: http://www.ukrstat.gov.ua/.

Triguero, A., Moreno-Mondéjar, L., Davia, M.A. (2013). Drivers of different types of eco-innovation in European SMEs. Ecological Economics, 92, 25-33.

Ukraine 2013 Enterprise Surveys. (2013). Accessed from: http://www.enterprisesurveys.org/data/ exploreeconomies/2013/ukraine.

Voicu-Dorobantu, R., Paraschiv, D.M., Marinoiu, A.M. (2011). Eco-innovation in Romanian SMEs. Recent Researches in Applied Economics, 1, 186-190. 